\title{
Intra-Zonal Differences in Roles among Gender in Farming Activities
}

\author{
Pratibha Singh, Poonam Tewari ${ }^{*}$ \\ Department of Home Science Extension, College of Home Science, G.B. Pant University of Agriculture and \\ Technology,Pantnagar-263145(Uttarakhand), India \\ *Corresponding author: aicrp_pant@rediffmail.com
}

\begin{abstract}
Women of hill region play a crucial role in food production, processing and have a vital role in conservation and management of sustainable eco-system. The role of women in bringing sustainable agricultural development needs to be documented and certified so as to address the issues pertinent to women empowerment as well as rural development. An attempt has been made in the present study to assess the difference in the roles, responsibilities, access and control of gender in farming activities. Data was collected from 2100 respondents of Tarai and Bhabhar zone and Hill zone of Uttarakhand state. Participatory interview technique was used to collect gender specific data. Interview schedule with codification was used for collection of the data. Intra-zonal differences in farming activities revealed that in Tarai and Bhabhar zone of Uttarakhand state independent roles and complete responsibilities of men dominated in crop production and post harvest management activities whereas in Hill zone women had independent roles and complete responsibilities.
\end{abstract}

Keywords Gender, roles, access and control

\section{Introduction}

The contribution of women in the economic development and social transformation are pivotal. Rural women who are engaged in agriculture form 78 per cent of all women in regular work. Women have an active role and extensive involvement in crop production, livestock production, forest resource management and fishery processing. Lal and Khurana [2011] in their study on "Gender issues: Role of women in agriculture sector" highlighted that rural women are the major contributors in agriculture and its allied fields. Her work ranges from crop production, livestock production to cottage industry, from household and family maintenance activities to transporting water, fuel and fodder. Despite such a huge involvement, her contribution in national economy has yet not been recognized. Women's equality is essential to a more holistic approach towards the process of development that is sustainable.

Uttarakhand is an agrarian state. Out of the total area, $64 \%$ of the land is under forest and only $14.02 \%$ is under cultivation. The state has two agro climate zones namely, Tarai and Bhabhar zone and Hill zone. The average landholding is around 0.68 ha (that too is divided into many patches) in the hills and 1.77 ha in Tarai and Bhabhar zone. About $70 \%$ of the hill population is engaged in agriculture. There is hardly any other source of livelihood from the secondary or tertiary sectors. These sectors are very poorly developed because of inaccessibility and vulnerability of mountain regions. Although almost $80 \%$ of the population of Uttarakhand is dependent on agriculture, the contribution of agriculture sector to the GDP is only 37.5. As a result it does not provide sufficient income levels to the people which in turn lead to a sizeable migration of male members that leads to only women headed families behind and the role of women in the household economy becomes more important.

Women of hill region play a crucial role in food production, processing and providing household food security. Chandra et.al [2009] in their study revealed that they work harder and for longer hours than men and have a vital role in conservation and management of sustainable eco-system. It is unfortunate that the actual and potential role of women in bringing about sustainable development remains concealed and unaccounted. The role of women in bringing sustainable agricultural development needs to be documented and certified so as to address the issues pertinent to women empowerment as well as rural development. Gender inequality hampers the overall development because restricting women from participation and decision making in social, political and economic activities can adversely affect the whole society. Women are not passive objects of assistance or policies but active subjects in social processes. Gender approach to development emphasizes the need to recognize the diversity of men and women, redefine development and transform gender relationship. With this point of view, an attempt has been made in the present study to assess the difference in the roles, responsibilities, access and control of gender in farming activities.

1. To study intra-zonal differences in roles and 
responsibilities of gender.

2. To study the differences in access and control of gender over various resources.

\section{Materials and Methods}

Data was collected from both the zones, Tarai and Bhabhar zone and Hill zone of Uttarakhand. Two districts namely, Udham Singh Nagar and Haridwar were selected from Tarai and Bhabhar zone and five districts namely Nainital, Almora, Champawat, Dehradun and Tehri Garhwal were selected from Hill zone.

Two blocks and five villages from each district were selected for data collection. Selection of villages was done purposively as farm families of different landholding categories were present in these villages, although the number of large and medium families was quite low. Thirty households were selected from each village, thus data was collected from a total of 1050 families. Participatory interview with one male and one female member of each family was conducted to collect gender specific data. Therefore, the total sample size for the present study consisted of 2100 respondents. Interview schedule with codification was used for collection of the data.

Descriptive cum exploratory design was selected for the study. Interview method was used for eliciting data from the respondents. Data was collected during the period 2007-2010. Data was analyzed using frequency, percentage and mean.

\section{Result and Discussion}

\section{Profile of the Respondents}

It includes age, education and occupation of the respondent.

Age

Age of the respondents was categorized as young (18-30 yrs.), Middle (31-45 yrs.) and upper age (46 yrs. and above).

Finding reveals that 51.34-64.00 per cent respondents (male and female) in both the zones, Tarai and Bhabhar and Hill, were of middle age group and 26.67-40.00 per cent respondents were of upper age i.e. 46 years and above. In Hill zone 19.73 per cent females were of younger age group whereas in Tarai and Bhabhar only 9.33 per cent females were young.

\section{Education}

Education of the respondents revealed that in Tarai \& Bhabhar and Hill zone nearly 28.00 per cent females were illiterate whereas approximately 6.00 per cent males were illiterate.

In Tarai and Bhabhar zone 30.00 per cent respondents had post matric diploma, 24.00 per cent were educated up to high school and 19.33 per cent were graduate or post graduate.

In Hill zone 29.68 per cent male respondents were high school, 19.65 per cent were educated up to middle school, 16.44 percent had post matric diploma and 16.31 per cent were graduate or post graduate.

\section{Occupation}

Occupation of the respondents was studied as farming, labour, service, enterprise and homemaking

Table 1. Intra zonal differences in profile of respondents

\begin{tabular}{|c|c|c|c|c|}
\hline & \multicolumn{2}{|c|}{ Tarai and Bhabhar zone } & \multicolumn{2}{|c|}{ Hill zone } \\
\hline & Female & Male & Female & Male \\
\hline \multicolumn{5}{|l|}{ Age } \\
\hline Young(18-30 yrs.) & 9.33 & 2.00 & 19.73 & 8.82 \\
\hline Middle ( $31^{`}-45$ yrs.) & 64.00 & 58.00 & 52.40 & 51.34 \\
\hline Upper(46 yrs. And above) & 26.67 & 40.00 & 27.87 & 39.84 \\
\hline \multicolumn{5}{|l|}{ Education } \\
\hline Illiterate & 28.00 & 6.67 & 28.40 & 5.48 \\
\hline Can read and write & 2.67 & 2.67 & 7.60 & 3.61 \\
\hline Primary school & 8.67 & 2.67 & 22.00 & 8.82 \\
\hline Middle school & 20.67 & 14.67 & 18.53 & 19.65 \\
\hline High school & 14.67 & 24.00 & 11.33 & 29.68 \\
\hline Post matric diploma & 12.67 & 30.00 & 7.33 & 16.44 \\
\hline Graduate and above & 12.67 & 19.33 & 4.80 & 16.31 \\
\hline \multicolumn{5}{|l|}{ Occupation } \\
\hline Farming & 0.67 & 78.67 & 80.67 & 35.56 \\
\hline Labour & 7.33 & 6.67 & 2.53 & 8.16 \\
\hline Service & 0.67 & 8.67 & 1.47 & 34.89 \\
\hline Enterprise & 0.00 & 6.00 & 0.80 & 21.26 \\
\hline Home making & 91.33 & 0.00 & 14.53 & 0.13 \\
\hline
\end{tabular}


Nearly 92 per cent women in Tarai \& Bhabhar zone were homemaker whereas 80.67 per cent women in Hill zone had farming occupation.

Regarding occupation of males in Tarai and Bhabhar zone 78.67 per cent males had farming as occupation, 8.67\% had service, 6.67 percent were labour and 6.00 per cent had enterprise as their occupation. In Hill zone only 35.56 per cent males had farming as occupation, 34.89 per cent had service and 21.26 per cent had enterprise as their occupation.

\section{Profile of the Farm Families}

This section of the study includes family education, family occupation, family type and landholding categories (table 2).

Family Education

In order to know the overall family education, information regarding education of all the members of each family was collected. Findings reveal that in both the zones more than 80.00 per cent family members of the farm families were educated. Education level was found to be higher in Hill zone. In hill zone 87.1 per cent family members of farm families were educated as against 80.4 per cent in Tarai and Bhabhar zone.

In Tarai and Bhabhar zone 18.2 per cent family members of farm families were graduate and above, 17.7 per cent had middle school education, 16.7 per cent were high school and 15.00 per cent had post matric diploma.

In Hill zone 18.4 per cent family members were educated upto middle school, 18.1 per cent were high school, 16.6 per cent had primary school and 14.4 per cent were graduate and above.

Family Occupation

Occupation of the farm families were farming, business, service and labour. Findings revealed that in Tarai and Bhabhar zone 79.33 per cent respondents had farming occupation, 8.67 were in service, 8.00 per cent were in business and 4.00 per cent were labour.

In Hill zone 56.13 per cent families had farming occupation, 27.87 per cent had service, 11.33 per cent had business and 4.67 per cent were labour.

Landholding

Landholding was categorized as landless (no land), small (less than 5 acres), medium (5.1-10 acres) and large (above 10 acres).

Data shows that in Tarai and Bhabhar zone 61.33 per cent families had small landholding, 17.33 per cent had medium landholding and 12.67 per cent were landless.

In Hill zone 90.93 per cent respondents had small landholding, 4.67 per cent were landless and 4.13 per cent had medium size of landholding i.e. 5.1-10 acres of land.

Table 2. Intra zonal differences in profile of the farm families

\begin{tabular}{|c|c|c|}
\hline & Tarai and Bhabhar zone & Hill zone \\
\hline \multicolumn{3}{|l|}{ FamilyEducation } \\
\hline Illiterate & 19.6 & 12.90 \\
\hline Can read and write & 3.20 & 6.50 \\
\hline Primary school & 9.60 & 16.60 \\
\hline Middle school & 17.70 & 18.40 \\
\hline High school & 16.70 & 18.10 \\
\hline Post matric diploma & 15.00 & 13.20 \\
\hline Graduate and above & 18.20 & 14.40 \\
\hline \multicolumn{3}{|l|}{ Family Occupation } \\
\hline Farming & 79.33 & 56.13 \\
\hline Business & 8.00 & 11.33 \\
\hline Service & 8.67 & 27.87 \\
\hline Labour & 4.00 & 4.67 \\
\hline \multicolumn{3}{|l|}{ Landholding category } \\
\hline landless(no land) & 12.67 & 4.67 \\
\hline Small (less than 5 acres) & 61.33 & 90.93 \\
\hline Medium(5.1-10 acres) & 17.33 & 4.13 \\
\hline Large(above 10 acres) & 8.67 & 0.27 \\
\hline
\end{tabular}




\section{Zone Wise Roles and Responsibilities of Gender}

In order to study intra zonal differences in roles and responsibilities of gender, farming activities were categorized into three activity areas as crop production activities, post harvest management activities and homestead gardening activities. Data for a number of sub activities was collected under each activity area. Mean scores were calculated to compare the average differences in the roles and responsibilities of women and men of Tarai and Bhabhar and; Hill zone (table 3).

Table 3. Zone wise role and responsibility of gender in various activity areas

Tarai and Bhabhar zone

\begin{tabular}{|c|c|c|c|c|c|c|c|c|}
\hline \multirow[b]{2}{*}{ Activity area } & \multicolumn{5}{|c|}{ Role } & \multicolumn{3}{|c|}{ Responsibility } \\
\hline & & Independent & $\begin{array}{c}\text { Joint } \\
\text { with } \\
\text { female }\end{array}$ & $\begin{array}{l}\text { Joint } \\
\text { with } \\
\text { male }\end{array}$ & $\begin{array}{c}\text { No } \\
\text { participation }\end{array}$ & Complete & Partial & $\begin{array}{l}\text { No } \\
\text { responsibility }\end{array}$ \\
\hline \multirow{2}{*}{$\begin{array}{c}\text { Crop } \\
\text { production }\end{array}$} & Female & 11.78 & 0.00 & 32.32 & 55.89 & 12.13 & 13.78 & 74.08 \\
\hline & Male & 55.74 & 14.23 & 0.56 & 29.47 & 64.33 & 1.69 & 33.98 \\
\hline \multirow{2}{*}{$\begin{array}{l}\text { Post harvest } \\
\text { management }\end{array}$} & Female & 18.39 & 0.11 & 24.36 & 57.12 & 17.2 & 23.6 & 59.2 \\
\hline & Male & 44.89 & 18.31 & 2.96 & 33.83 & 50.84 & 15.75 & 33.41 \\
\hline \multirow{2}{*}{$\begin{array}{c}\text { Homestead } \\
\text { gardening }\end{array}$} & Female & 33.81 & 0.00 & 20.74 & 45.45 & 35.79 & 13.07 & 51.13 \\
\hline & Male & 11.54 & 41.96 & 6.29 & 40.21 & 30.42 & 23.77 & 45.80 \\
\hline
\end{tabular}

Hill zone

\begin{tabular}{|c|c|c|c|c|c|c|c|c|}
\hline \multirow[b]{2}{*}{ Activity area } & \multicolumn{5}{|c|}{ Role } & \multicolumn{3}{|c|}{ Responsibility } \\
\hline & & Independent & $\begin{array}{c}\text { Joint } \\
\text { with } \\
\text { female }\end{array}$ & $\begin{array}{l}\text { Joint with } \\
\text { male }\end{array}$ & $\begin{array}{c}\text { No } \\
\text { participation }\end{array}$ & Complete & Partial & $\begin{array}{c}\text { No } \\
\text { responsibility }\end{array}$ \\
\hline \multirow{4}{*}{$\begin{array}{c}\text { Crop production } \\
\text { Post harvest } \\
\text { management }\end{array}$} & Female & 52.61 & 9.87 & 28.70 & 8.81 & 52.33 & 36.91 & 10.75 \\
\hline & Male & 26.14 & 46.01 & 3.33 & 24.50 & 31.99 & 42.80 & 25.19 \\
\hline & Female & 58.21 & 10.65 & 24.16 & 6.97 & 67.55 & 23.62 & 8.82 \\
\hline & Male & 23.86 & 47.78 & 2.27 & 26.09 & 27.85 & 45.95 & 26.20 \\
\hline \multirow{2}{*}{$\begin{array}{c}\text { Homestead } \\
\text { gardening }\end{array}$} & Female & 66.47 & 12.46 & 19.43 & 1.63 & 78.07 & 19.33 & 2.59 \\
\hline & Male & 14.25 & 56.07 & 1.41 & 28.26 & 17.58 & 54.11 & 28.30 \\
\hline
\end{tabular}

\section{Crop Production Activities}

It includes ploughing, seed selection, transplanting, weeding, harvesting, application of manure/fertilizers and insect/pest management. Mean scores indicate that $55.74 \mathrm{per}$ cent men of Tarai and Bhabhar zone had independent roles in crop production. Only 44.11 per cent women were participating in crop production activities, out of this 32.32 per cent women were jointly involved with men. Nearly 65.00 per cent men had independent responsibilities in crop production activities.

In Hill zone, 52.61 per cent women had independent roles and complete responsibilities of crop production activities. Nearly 28.70 per cent women were participating with men and 26.91 per cent had partial responsibility. Forty six per cent men were jointly participating in crop production activities and only 42.80 were having partial responsibilities in crop management activities. Kishtwaria[3] also found that women in hill region perform crop production activities independently i.e. transplanting, cutting/uprooting, weeding and transporting manure.

\section{Post Harvest Management Activities}

It includes threshing, winnowing, cleaning, drying, management of surplus produce, storage, marketing and management of cash.

On an average 55.89 per cent woman of Tarai and Bhabhar zone were not involved in post harvest management activities. Nearly 25.00 per cent were participating jointly with men and 18.39 per cent were independently performing post harvest management activities. On the other hand 44.89 per cent males were independently performing post harvest management activities and also had complete responsibilities of post harvest management activities.

In contrast to Tarai \& Bhabhar in Hill zone, 58.21 per cent women were independently performing the roles and had responsibility in post harvest management activities. Only 24.16 per cent women were jointly performing the roles and sharing responsibilities of these activities with males. Regarding the role of men, 47.78 per cent were jointly performing post harvest activities with women and 23.86 per cent were independently performing. Chandra et al.(2009) also revealed that women of hill region contribute more in crop production and post harvest management activities including sorting, grading, cleaning and storage.

Homestead Gardening

Mean scores regarding various homestead gardening 
activities reveals that in Tarai and Bhabhar zone 45.45 per cent women were not participating in homestead gardening activities. One-third women (33.81\%) had independent roles and were fully responsible for homestead gardening and; 20.74 per cent women were jointly performing homestead gardening activities (table 3). Men were participating in homestead gardening jointly with women and had partial responsibility of these activities.

In contrast majority of the hill women were independently performing $(66.47 \%)$ homestead gardening activities and had complete responsibility of homestead gardening whereas 56.07 per cent males were jointly involved with women and 54.11 per cent males were sharing the responsibility of homestead gardening with women.

\section{Zone Wise Comparison of Access and Control over Resources}

Access and control of gender were studied as complete, partial and no access/control. In order to study the intra zonal difference in access and control, data regarding various farming resources i.e. sale and purchase of land, farm assets, farm inputs, farm produce, management of labour, marketing and management of cash and credit were collected from the respondents. Mean scores of access and control were calculated to compare the average differences in the access and control of women and men of Tarai and Bhabhar and Hill zone.

Data as shown in table 4 reveals that in Tarai and Bhabhar zone nearly 85.00 per cent men had complete access and control over farm related resources whereas in Hill zone almost 51.00 per cent male had partial access \& control and 41.00 per cent had independent access and control over farm related resources.

As women in Tarai zone rarely participate in farming activities they had very little access and control over the farm resources. In Hill zone women perform majority of the activities alone but had only partial access and control over the resources. Hill men had more access and control over those resource which involves finance i.e. purchase/sale, marketing and management of cash.

Table 4. Zone wise access and control of gender over resources in farming activities

\begin{tabular}{|c|c|c|c|c|c|c|c|}
\hline \multicolumn{2}{|c|}{ Major resources } & \multicolumn{3}{c|}{ Access } & \multicolumn{3}{c|}{ Control } \\
\hline \multirow{2}{*}{ Tarai and Bhabhar zone } & Female & 4.01 & 14.12 & 81.87 & 3.25 & 11.62 & 85.13 \\
\cline { 2 - 9 } & Male & 83.19 & 9.37 & 7.43 & 86.08 & 6.63 & 7.29 \\
\hline \multirow{2}{*}{ Hill zone } & Female & 23.54 & 39.92 & 36.53 & 23.55 & 39.94 & 36.41 \\
& Male & 40.85 & 50.53 & 8.62 & 41.73 & 51.02 & 7.24 \\
\hline
\end{tabular}

\section{Conclusion}

Intra-zonal differences in farming activities revealed that in Tarai and Bhabhar zone of Uttarakhand state independent roles and complete responsibilities of men dominated in crop production and post harvest management activities whereas in Hill zone independent roles and complete responsibilities of women dominated. Homestead gardening activities were independently performed by women in both the zones and they were responsible for these activities in majority of the households.

Regarding access and control of gender study reveals that in Tarai and Bhabhar zone men had independent access and control over various farm resources whereas in Hill zone both men and women had equal access and control over majority of the resources even though the role and responsibility of men is found to be less than hill women.

Women are the backbone of hill agriculture and play a significant role in management of natural resources. They work harder and for longer hours than men and have a vital role in conservation and management of sustainable eco-system. Documentation of role of hill women would be helpful in planning programmes and policies for hill development. As women work more and hold greater responsibility there is need of technological empowerment of women to address the issues of gender equality and sustainable development.

\section{REFERENCES}

1. Chandra A., Kandari R. and L.S., 2009. Role of Rural and Tribal Women in Conservation of Village Ecosystem: A Case Study of Nanda Devi Biosphere Reserve, India, Environment and We: An International Journal of Science and Technology, Vol.4, 
pp.29-34.

2. Kishtwaria, J., Aruna R. and Sood, S, 2009. Work Pattern of hill farm women-A study of Himachal Pradesh, stud home comm. Sci, Vol.3, No.1, pp.67-70.

3. Lal, Roshan and Khurana, Ashok. 2011. Gender issues: Role of women in agriculture sector. ZENITH, International Journal of Business Economics \& Management Research Vol.1, No. 1, Oct, ISSN 22498826. 